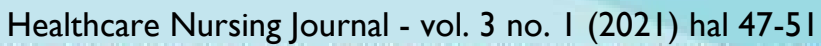

\section{PENGARUH REBUSAN DAUN SALAM TERHADAP PENURUNAN KADAR ASAM URAT PADA LANSIA (LITERARURE REVIEW)}

\author{
Pandu Patyawargana ${ }^{1}$, Miftahul Falah ${ }^{2}$ \\ Fakultas IImu Kesehatan Universitas Muhammadiyah Tasikmalaya
}

\section{Article Information}

Received: Desember 3th, 2020

Revised: January 1th, 2021

Available online: January, 2021

\section{Keywords}

Rebusan Daun Salam,

Penurunan Kadar Asam Urat, Gout Arthitis

\section{Correspondence}

Phone: (+62)82216236298

E-mail:

Pandumas808@gmail.com

\begin{abstract}
Tingginya angka kejadian penyakit gout artritis di masyarakat yang dapat menimbulkan dampak yang cukup serius. Untuk mencegah atau menurunkan kadar urat meningkat yaitu dengan memanfaatkan tumbuhan alami berupa daun salam. Daun salam mengandung flavonoid yang mampu menurunkan kadar asam urat. Tujuan penelitian ini adalah untuk mengetahui pengaruh rebusan daun salam terhadap penurunan kadar asam urat lansia. Metode penelitian ini adalah literature Review melalui pencarian artikel yang dilakukan di internet dengan search engine Google Scholar dan Portal Garuda, terdiri dari 120 populasi didapat 8 jurnal full text yang sesuai kriteria inklusi. Hasil penelitian bahwa daun salam terbukti efektif menurunkan kadar asam urat pada penderita gout arthitis. Daun salam mempunyai kandungan yang bermanfaat bagi penderita gout arthitis yaitu diantaranya flavonoid. Kesimpulan dari penelitian ini adalah bahwa ada pengaruh rebusan daun salam terhadap penurunan kadar asam urat pada lansia penderita gout artritis. Sehingga disarankan dalam melakukan penatalaksanaan penurunan kadar asam urat pada penderita gout artritis dapat melakukan dengan cara mengkonsumsi rebusan daun salam.
\end{abstract}

\section{PENDAHULUAN}

Angka kejadian penyakit asam urat di dunia saat ini cukup tinggi. World Health Organization (2014) melaporkan bahwa asam urat mempengaruhi sekitar $1-2 \%$ populasi di Barat Amerika Serikat. peningkatan jumlah kasus asam urat meningkat hampir dua kali lipat antara tahun 2006 sampai 2010. Peningkatan ini diprediksi terjadi karena meningkatnya angka harapan hidup, perubahan jenis makanan dan tingginya penyakit yang berhubungan dengan asam urat. Indonesia termasuk Negara terbesar keempat didunia yang penduduknya menderita arthritis gout. Penyakit asam urat 35\% terjadi pada pria diatas umur 45 tahun. Indonesia Prevalensi penyakit sendi pada usia 55-64 tahun $45 \%$. Usia $65-74$ tahun 51,9\%. Usia $\geq 75$ tahun 54,8\%. Kejadian penyakit sendi berdasarkan diagnosis tenaga Kesehatan di Indonesia 7,3 dan berdasarkan diagnosis atau gejala 24,7\% (RISKESDAS,2018). 
Penyakit Arthritis Gout merupakan peradangan pada sendi akibat tingginya kadar asam urat dalam darah, karena terganggunya metabolisme purin (hiperurisemia) dalam tubuh. Ditandai dengan nyeri sendi, sehingga dapat mengganggu aktivitas penderita (Cumayunaro, 2017). Pada keadaan ini bisa terjadi oversekresi asam urat, atau penurunan fungsi ginjal. Sehingga mengakibatkan penurunan ekresi asam urat, atau kombinasi keduanya (Andriani dan Chaidir, 2016). Kadar Asam urat yang tinggi dalam darah, dalam jangka waktu lama dapat menyebabkan pembentukkan kristal urat yang biasanya terkonsentrasi pada sendi dan jaringan sekitarnya. Kristal ini lama kelamaan menumpuk dan merusak jaringan dan akhirnya menimbulkan rasa nyeri dan peradangan. Adapun sendi yang sering terkena penumpukkan asam urat ini antara lain pangkal ibu jari kaki, lutut, pergelangan kaki, pergelangan tangan dan siku (Rusita, 2016).

Artritis gout penyakit yang sangat mengganggu aktivitas pasiennya. Penderita arthritis gout akan merasa nyeri, sendi-sendi sakit saat digerakkan, bengkak, jari-jari tangan terasa kaku jika digerakkan, sehingga membuat mereka tidak mampu bekerja dan beraktivitas. Pada kasus yang parah, seseorang bisa mengalami benjolanbenjolan aneh yang timbul disekujur tubuh. Kemudian benjolan tersebut meletus dan membuat luka yang besar dan sangat sakit. Melihat dampak-dampak yang disebabkan asam urat, terlihat sangat jelas bahwa penyakit ini bukanlah penyakit yang biasa-biasa saja. Penyakit ini bisa digolongkan kedalam jenis penyakit yang berbahaya. Penanganan yang tidak tepat dapat menyebabkan bahaya lebih besar, sehingga dibutuhkan penatalaksanaan farmakologi maupun non farmakologi (Marlinda dan putri, 2019).

Terapi komplementer merupakan salah satu solusi dalam penanganan penyakit asam urat. Pengobatan dengan menggunakan terapi komplementer mempunyai manfaat selain dapat meningkatkan kesehatan secara menyeluruh juga lebih murah, manfaat pengobatan dengan menggunakan terapi komplementer dirasakan oleh pasien dengan penyakit kronik yang mengeluarkan dana. Pengalaman klien yang harus membeli obat dengan harga yang mahal membuat pengeluaran dana untuk membeli obat dapat berkurang setelah menggunakan pengobatan komplementer. Daun salam (Syzygium Polyanthum Wight) bermanfaat untuk peluruh kencing (diuretik) dan anti nyeri (analgesik). Kandungannya sebagai diuretik, daun salam dapat memperbanyak produksi urine sehingga dapat menurunkan kadar asam urat darah (Widiyono dkk, 2020).

Menurut Marlinda dan Putri (2019) mengatakan pemberian rebusan daun salam sebanyak $100 \mathrm{cc}$ yang di buat dengan merebus 5-7 lembar daun salam dengan 1000 cc air menjadi 100 cc, dan diberikan kepada responden $2 x$ sehari selama 7 hari terbukti menurunkan kadar asam urat pada penderita gout arthitis di Puskesmas Alai Kota Padang. Sejalan dengan penelitian yang dilakukan oleh Widiyono, dkk (2020) yang meneliti tentang pengaruh rebusan daun salam terhadap penurunan kadar asam urat pada lansia. Berdasarkan hasil uji statistik menggunakan Wilcoxon signed rank test diperoleh $p$ value 0,000 lebih kecil a dengan kata rebusan daun salam efektif menurunkan kadar asam urat pada penderita gout arthritis.

\section{METODE}

Desain penelitian ini adalah Literature Review atau tinjauan pustaka. Tujuan penelitian literature review ini adalah untuk melihat pengaruh rebusan daun salam terhadap penurunan kadar asam urat pada lansia, variabel dalam penelitian ini terdiri dari variabel independent (variabel bebas) yaitu rebusan daun salam dan variabel dependent (variabel terikat) yaitu kadar asam urat pada penderita gout arthitis. Adapun yang menjadi populasi di penelitian ini adalah jurnal nasional yang pengaruh rebusan daun salam terhadap penurunan kadar asam urat pada 
lansia. Jumlah populasi sebanyak 120 artikel dan diperoleh 8 artikel yang termasuk ke dalam kriteria inklusi. Pengambilan sampel pada penelitian ini dilakukan dengan cara mengakses database (Google Scholar, Portal Garuda) dengan keyword (kata kunci) sesuai dengan masalah pada penelitian sebagai berikut : : Rebusan Daun Salam , Penurunan Kadar Asam Urat, Gout Arthitis. Kriteria inklusi dalam penelitian ini adalah : Jurnal nasional yang berkaitan dengan rebusan daun salam, penurunan kadar asam urat, gout arthitis, Jurnal nasional yang membahas terapi komplementer pada penderita Gout Arthitis, Jurnal nasional dengan tahun terbit 2010-2020, Jurnal nasional yang dapat di akses dengan full text. Dalam penelitian ini menggunakan tahapan literature review. Adapun tahapan yang telah dilakukan adalah tahapan identifikasi, screening, penilaian kualaitas, analisa data dan menulis hasil analisa data.

\section{HASIL DAN PEMBAHASAN}

Berdasarkan hasil analisa data pada 8 artikel dapat disimpulkan terdapat perbedaan yang signifikan rebusan daun salam sebanyak $100 \mathrm{cc}$ yang di buat dengan merebus 5-7 lembar daun salam dengan 1000 cc air menjadi 100 cc, dan diberikan kepada responden $2 x$ sehari selama 7 hari dapat menurunkan kadar asam urat pada penderita gout arthitis dibandingkan dengan sebelum diberikan perlakuan rebusan daun salam (Widiyono dkk, 2020; Vechya dkk, 2019; Marlinda dan Putri, 2019; Alvita dan Irma, 2018; Fariz dkk, 2018; Cumayunaro, 2017; Andriani dan Chaidir, 2016; Madyastuti, 2014)

Meningkatnya level hidup masyarakat terutama di negara maju dan kota besar membawa perubahan pada pola hidup setiap individu (Tumenggung, 2015). Perubahan pola hidup yang dapat menurunkan status kesehatan pada seseorang salah satunya ialah pola makan. Perubahan pola makan yang mengandung banyak karbohidrat dan serat ke pola makan yang banyak mengandung protein, kalori, dan banyak mengandung purin dapat mengakibatkan kadar asam urat dalam darah meningkat dan akan menimbulkan penumpukan kristal asam urat. Penumpukan asam urat dalam darah akan menyebabkan terjadinya penyakit gout artritis (Wirahmadi, 2013).

Berdasarkan analisis antara fakta dan teori, peneliti berpendapat bahwa terjadinya peningkatan kadar asam urat di dalam darah dapat disebabkan oleh beberapa faktor seperti pembuangan asam urat yang terganggu, faktor usia, dan juga bisa disebabkan oleh faktor makanan yaitu dengan mengkonsumsi makanan yang mengandung tinggi purin seperti kacang tanah, bayam, buncis, daun singkong, daging, kembang kol dan kangkung (Cumayunaro, 2017; Andriani dan Chaidir, 2016; Madyastuti, 2014). Menurut Anjarwati (2012), penumpukan kadar asam urat pada laki-laki disebabkan dari beberapa faktor yaitu faktor makanan tinggi purin, usia, obat-obat tertentu dan mengkonsumsi alkohol. Produksi asam urat di dalam tubuh meningkat, ini merupakan penyebab karena mengkonsumsi makanan yang berkadar tinggi purin seperti daging, jeroan, bayam, kacang, kangkung, kerang, kembang kol, buncis, dan kepiting. Keadaan ini akan membuat metabolisme makanan tersebut membentuk asam urat yang akhirnya membuat tingginya kadar asam urat dalam darah.

Gouth artritis merupakan salah satu jenis penyakit radang sendi atau inflamasi pada sendi yang disebabkan oleh pengendapan kristal monosodium urat dalam jaringan sinovisial dan jaringan lainnya (Neogi, 2011). Gout artritis akan menyebabkan kadar asam urat penderita meningkat dan juga penderita akan merasa nyeri, bengkak, kemerahan, dan hangat pada persendian. Apabila gejala yang timbul tidak diobati akan menyebabkan kerusakan pada sendi. Penanganan yang dilakukan untuk mencegah terjadinya peningkatan kadar asam urat dalam darah, antara lain pengaturan diet, menghindari makanan tinggi purin, konsumsi vitamin dan mineral yang cukup, olahraga rutin, berhenti merokok, pengendalian stres dan dapat diberikan obat-obatan untuk terapi farmakologi. 
Pengobatan lain yang dapat digunakan untuk mengatasi peningkatan kadar asam urat yaitu dengan pengobatan herbal (Sari \& Syamsiyah, 2017). Masyarakat Indonesia menggunakan tanaman berkhasiat sebagai salah satu upaya untuk menanggulangi berbagai masalah kesehatan seperti gout artritis (Fariz dkk, 2018). Tanaman herbal yang berkhasiat mengatasi penyakit gout artritis salah satunya yaitu rebusan daun salam (Utami \& Puspaningtyas, 2013). Daun salam mengandung flavonoid yang berfungsi untuk menurunkan kadar asam urat dalam darah dan membantu dalam pengeluaran asam urat melalui urin (Ekasari, 2018; Vechya dkk, 2019).

Menurut Marlinda dan putri (2019) mengatakan pemberian rebusan daun salam sebanyak $100 \mathrm{cc}$ yang di buat dengan merebus 5-7 lembar daun salam dengan 1000 cc air menjadi 100 cc, dan diberikan kepada responden $2 x$ sehari selama 7 hari terbukti menurunkan kadar asam urat pada penderita gout arthitis di Puskesmas Alai Kota Padang. Sejalan dengan penelitian Widiyono dkk, (2020) yang meneliti tentang pengaruh rebusan daun salam terhadap penurunan kadar asam urat pada lansia. Berdasarkan hasil uji statistik menggunakan Wilcoxon signed rank test diperoleh $p$ value 0,000 lebih kecil a dengan kata rebusan daun salam efektif menurunkan kadar asam urat pada penderita gout arthritis. Menurut penelitian yang dilakukan oleh Alvita dan Irma (2018) dengan judul penelitian pengaruh rebusan daun salam terhadap penurunan kadar asam urat lansia. Diperoleh hasil univariat, bahwa kadar asam urat darah sebelum diberikan air rebusan daun salam yaitu rata-rata $8,8 \mathrm{mg} / \mathrm{dl}$, sedangkan setelah diberikan air rebusan daun salam menjadi 7,5 mg/dl. Penelitian lain tentang khasiat daun salam dikemukakan oleh Andoko dan Dimas (2016) mengatakan bahwa daun salam selain bermanfaat untuk menurunkan kadar asam urat, daun salam juga mampu menurunkan tekanan darah pada penderita hipertensi karena daun salam memiliki senyawa flavonoid yang dapat menurunkan systemic vascular resisten (SVR) karena menyebabkan vasodilatasi dan mempengaruhi kerja angiotensin converting enzyme (ACE) yang mampu menghambat terjadinya perubahan angiotensi I menjadi angiotensin II. Efek vasodilatasi dan inhibitor ACE dapat menurunkan tekanan darah. Dengan demikian daun salam dapat bertindak sebagai penurun tekanan darah.

\section{KESIMPULAN DAN SARAN}

Kesimpulan dari penelitian ini adalah bahwa ada pengaruh rebusan daun salam terhadap penurunan kadar asam urat pada lansia penderita gout artritis. Penelitian ini menyarankan dalam melakukan penatalaksanaan penurunan kadar asam urat pada penderita gout artritis dapat dilakukan dengan cara mengkonsumsi rebusan daun salam yang terbukti memiliki pengaruh yang signifikan.

\section{DAFTAR PUSTAKA}

Andriani, A., \& Chaidir, R. (2016). Pengaruh pemberiaan air rebusan daun salam (syzygium polyanthum) terhadap penurunan kadar asam urat. Jurnal Ipteks Terapan. Volume 10 (2), 112-119.

Andoko dan Dimas Ning Pangesti. 2016. Efektifitas Rebusan Daun Salam Terhadap Penurunan Tekanan Darah Pada Penderita Hipertensi. Jurnal Kesehatan Holistik (The Journal of Holistic Healthcare). Volume 10 (2), 1-4.

Anjarwati, W. (2012). Tulang dan Tubuh Kita. Yogyakarta: Getar Hati.

Alvita Helvi dan Irma Fidora, 2018. Pengaruh Rebusan Daun Salam Terhadap Penurunan Kadar Asam Urat Lansia. Jurnal Menara Medika. Volume 1 (1), 11-21.

Cumayunaro, A. 2017. Rebusan Daun Salam Untuk Penurunan Kadar Asam Urat Dan Intesitas Nyeri Arthritis Gout Di Puskesmas Andalas 
Padang. Stikes Ranah Minang Padang. Kota Padang

Ekasari, W, 2018. Tanaman dan Kesehatan, Terapi Alternatif Tiga Penyakit Utama dengan Bukti Ilmiah. Indomedika Pustaka: Sidoarjo.

Fariz, A., Sholihin, M.A., Fauzi, R., \& Rizki, M.I. (2018). Riview: tanaman obat yang berefek sebagai antigout. Jurnal Pharmascience. Volume 5 (1), 22-3.

Marlinda Roza dan Putri Dafriani. 2019. Pengaruh Pemberian Air Rebusan Daun Salam Terhadap Penurunan Kadar Asam Urat Pasien Arthritis Gout. Jurnal Kesehatan Saintika Meditory, Volume 2 (1), 62-70.

Ndede Vechya Z.L.P, dkk. 2019. Pengaruh Pemberian Rebusan Daun Salam Terhadap Penurunan Kadar Asam Urat Pada Penderita Gout Artritis Di Wilayah Kerja Puskesmas Ranotana Weru. E-journal Keperawatan (eKp).Volume 7 (1), 1-8.

Neogi, T. (2011). Gout. New England Journal Of Medicine. Volume 364 (5), 443-452.

R Lina Madyastuti dan Nanang Dwi Septiadi. 2014. Rebusan Daun Salam Menurunkan Kadar Asam Urat Pasien Gout. Journals of Ners Community. Volume 5 (1), 1-9.

RISKESDAS. 2018, Badan Penelitian Dan Pengembangan Kesehatan. Kementrian Kesehatan: RI.

Rusita, Y.D., 2016, Terapi Herbal Buah \& Sayuran Untuk 10 Penyakit Berbahaya.Yogyakarta

Sari, Y. A \& Syamsiyah, N. (2017). Berdamai Dengan Asam Urat. Tim Bumi Medika: Jakarta.

Tumenggung, I. (2015). Hubungan pola makan dengan kejadian gout arthritis di rsud toto kabila kabupaten bone bolango. Journal Health And Nutrition. Volume 1(2), 1-12.

Utami, P. \& Puspanintiyas E.D. (2013). The Miracle of Herbs. PT. Agromedia Pustaka: Jakarta

Widiyono, dkk. 2020. Pengaruh Rebusan Daun Salam Terhadap Penurunan Kadar Asam Urat Pada Lansia. Jurnal Perawat Indonesia. Volume 4 (2), 79-89.
Wirahmadi, I. K. N. (2013). Pengaruh pemberian rebusan daun sirsak terhadap nyeri pada penderita gout di kelurahan genuk barat kecamatan Unggaran barat kabupaten Semarang.

World Health Organization. (2014). Global status report on noncommunicable diseases 2014 (No. WHO/NMH/NVI/15.1). World Health Organization. 